\title{
Books by Our Readers
}

\author{
Anatomy of a False Confession: \\ The Interrogation and Conviction of \\ Brendan Dassey \\ Michael Cicchini \\ Rowman \& Littlefield Publishers
}

Anthropocene Encounters: New Directions in Green Political Thinking

Frank Biermann and Eva Lövbrand, editors

Cambridge University Press

Bobbio e Sartori. Capire e cambiare 1a politica

Gianfranco Pasquino

Egea-Unibocconi

Colonial Capitalism and the Dilemmas of Liberalism

Onur Ulas Ince

Oxford University Press

Covert Regime Change:

America's Secret Cold War

Lindsey A. O'Rourke

Cornell University Press

Foundations of Agnostic Statistics

Peter M. Aronow and Benjamin T. Miller Cambridge University Press

\section{The Foundations of}

American Jewish Liberalism

Kenneth D. Wald

Cambridge University Press

Game Theory, Diplomatic History

and Security Studies

Frank C. Zagare

Oxford University Press
God Against the Revolution:

The Loyalist Clergy's Case Against the

American Revolution

Gregg L. Frazer

University Press of Kansas

Happiness in the Wrong Metric: A Liberal Communitarian Response to Populism

Amitai Etzioni

Springer

Just Giving: Why Philanthropy is Failing

Democracy and How it Can Do Better

Rob Reich

Princeton University Press

Law and Society in a Populist Age:

Balancing Individual Rights

Amitai Etzioni

Bristol University Press

The Myth of Coequal Branches: Restoring the Constitution's Separation of Functions David J. Siemers

University of Missouri Press

Now That's Funny:

A Memoir on Passing Through

Charles O. Jones

iUniverse

Party Institutionalization and Women's Representation in Democratic Brazil Kristin N. Wylie

Cambridge University Press

Political Parties in the UK, 2nd Edition

Alistair Clark

Palgrave
Segregation by Design: Local Politics and Inequality in American Cities

Jessica Trounstine

Cambridge University Press

Strong Governments, Precarious Workers: Labor Market Policy in the Era of Liberalization

Philip Rathgeb

Cornell University Press

Varieties of Capital Cities:

The Competitiveness Challenge for

Secondary Capitals

David Kaufmann

Edward Elgar Publishing

When Right Makes Might: Rising Powers and World Order

Stacie E. Goddard

Cornell University Press

White Identity Politics

Ashley Jardina

Cambridge University Press

Winning Hearts and Votes: Social Services and the Islamist Political Advantage

Steven Brooke

Cornell University Press

\section{Keep PS Informed}

Let us know about your new book. Email PS editorial associate Nick Townsend at ntownsend@apsanet.org to submit your title, or with any questions. 